\title{
Sosialisasi Sejarah Bank Perkreditan Rakyat (BPR) Dan Bank Perkreditan Rakyat Syariah (BPRS) Kepada Alumni Pondok Al-Iman Yang Berada Di Palembang
}

\author{
${ }^{1}$ Meriyati, ${ }^{2}$ Agus Hermanto \\ ${ }^{1}$ Program Studi Perbankan Syariah STEBIS IGM Palembang \\ ${ }^{2}$ Fakultas Syari'ah UIN Raden Intan Lampung \\ Email : meri@stebisigm.ac.id, gusger.sulthani@radenintan.ac.id
}

\begin{abstract}
Rural Banks are bank financial institutions, which accept deposits only in the form of time deposits, savings, and / or other equivalent forms and channel funds as an RB business. The People's Credit Institution originated in the Dutch colonial period in the 19 th century, with the formation of the Village Lumbung, Village Bank (BD), Bank Tani (BT), and Bank Dagang Desa (BDD), with the aim of helping farmers, employees and laborers to releasing themselves from the trap of moneylenders (loan sharks) who are said to provide loans with high interest rates. With the issuance of Law no. 7 concerning Banking of 1992 (Law No. 7/1992 concerning Banking) provided a clear legal basis as a type of bank other than commercial banks. According to Law no. 7/1992 concerning Banking Non-bank financial institutions that have obtained a business license from the minister of finance may adjust their business activities as a bank.
\end{abstract}

Keywords: History of Banks, Rural Banks, Sharia Rural Banks

\begin{abstract}
Abstrak
Bank Perkreditan Rakyat adalah lembaga keuangan bank, yang menerima simpanan hanya dalam bentuk deposito berjangka, tabungan, dan/atau bentuk lainnya yang dipersamakan dengan itu serta menyalurkan dana sebagai usaha BPR. Lembaga Perkreditan Rakyat bermula pada masa kolonial Belanda pada abad ke-19, dengan dibentuknya Lumbung Desa, Bank Desa (BD), Bank Tani (BT), dan Bank Dagang Desa (BDD), dengan tujuan membantu para petani, pegawai, dan buruh untuk melepaskan diri mereka dari jerat pelepas uang(rentenir) konon memberikan kredit dengan bunga tinggi. Dengan dikeluarkannya Undang Undang No. 7 tentang Perbankan tahun 1992 (UU No. 7/1992 tentang Perbankan) diberikan landasan hukum yang jelas sebagai salah satu jenis bank selain bank umum. Sesuai UU No. 7/1992 tentang Perbankan Lembaga Keuangan Bukan Bank yang telah memperoleh izin usaha dari menteri keuangan dapat menyesuaikan kegiatan usahar sebagai Bank.
\end{abstract}

Kata Kunci: Sejarah Bank, Bank Perkreditan Rakyat, Bank Perkreditan Rakyat Syariah

\section{Pendahuluan}

Pascakemerdekaan Indonesia, didirikan beberapa jenis lembaga keuangan kecil dan lembaga keuangan di pedesaan seperti Bank Pasar, Bank Karya 
Produksi Desa (BKPD), dan mulai awal 1970-an, Lembaga Dana Kredit Pedesaan (LDKP) oleh Pemerintah Daerah. Pada tahun 1988, Pemerintah mengeluarkan kebijakan, pada bulan Oktober 1988 (PAKTO 1988) melalui Keputusan Presiden Republik Indonesia No. 38 yang menjadi momentum awal pendirian. Kebijakan tersebut memberikan kejelasan mengenai keberadaan dan kegiatan usaha bank perkreditan rakyat atau BPR. Sedangkan BPRS suatu lembaga/badan yang Mengelola dana umat yang ingin terbebas dari unsur riba, membantu pengembangan usaha dengan berbagai jenis produk pembiayaan, melayani usaha mikro dan kecil (UKM) dengan proses mudah. cepat dan persyaratan ringan, membina dan meningkatkan semangat ukhuwah Islamiah melalui pemberdayaan ekonomi kerakyatan. (https://www.bpramira.com/2018/07/12/sejarah-singkat-bprbank-perkreditan-rakyat/)

Banyak masyarakat yang belum paham mengenai: Sejarah BPR dalam Sistem Keuangan di Indonesia, Arsitektur Perbankan Indonesia (API), Posisi Strategis Bank Perkreditan Rakyat, Struktur Mekanisme Pengelolaan Bank Perkreditan Rakyat, Kebijakan Penerimaan dan Identifikasi Nasabah, Kebijakan Pemantauan Dan Pelaporan, Prosedur Penerimaan Nasabah, Sejarah Bank Pembiayaan Rakyat Syariah (BPRS), Usaha-Usaha BPR Syariah, Modal Pendirian BPRS, Ketentuan Kehati-Hatian BPRS. Tujuan yang hendak dicapai dari dual banking system dalam kerangka Arsitektur Perbankan Indonesia (API) adalah agar sistem perbankan syariah dan konvensional secara sinergis dapat mendukung mobilisasi dana masyarakat secara lebih luas guna meningkatkan kemampuan perbankan memberikan pembiayaan bagi sektor-sektor perekonomian nasional (Bank Indonesia, Sekilar Perbankan Syariah Di Indonesia, http://www.bi.go.id/web/id/Perbankan/Perbankan+Syariah/ diakses 25 Agustus 2012)

Target kami dalam melakukan sosialisasi ini adalah agar para alumni pondok pesantren Al-Iman yang ada di Palembang lebih memahami sejarah BPR dan BPRS. sehingga dapat membuka semangat mereka untuk tidak khawatir, bimbang dan bingung dalam mencari modal membuka usaha kecil/mikro demi meningkatkan pemasukan ekonomi pribadi serta membatu keluarga pada masa pandemi covid-19. BPR dan BPRS selalu berusaha menjadi lembaga yang sehat dan handal dan Profesional menjadi mitra pemerintah dan masyarakat untuk meningkatkan kesejahteraan ummat, dengan pengembangan perekonomian sesuai tuntutan peraturan masing-masing lembaga keuangan baik berbasis konvensional maupun syariah Islam, sehingga dapat membantu Beberapa sektor usaha terdampak wabah pandemi virus korona (Covid-19), termasuk di dalamnya adalah sektor perbankan, hadirnya BPRS agar menjadi sektor perbankan dapat tetap eksis di tengah pandemi Covid-19.

\section{Metode Pengabdian}

Kegiatan pengabdian kepada masyarakat terdiri dari beberapa kegiatan.

\section{Tahap-1 : Persiapan Pelaksanaan AKM}

Kegiatan Pengabdian ini melibatkan kepanitiaan reuni alumni Pondok AlIman yang ada di Palembang dengan pembagian tugas masing-masing ada yang mensurvey lokasi, pembuatan undangan kehadiran para alumni, konsumsi, serta menyiapkan materi yang diperlukan.

2. Tahap-2 : Observasi lokasi 
Pada saat proposal ini diajukan, tim pengabdian telah mendapatkan persetujuan untuk melaksanakan kegiatan pengabdian di lokasi. Untuk memantapkan rencana tersebut, maka tim pengabdian akan berdiskusi dengan para panitia alumni menetapkan jadwal yang fix, teknis kegiatan, tempat pelaksanaan, target peserta dan sistem sosialisasi yang akan diberikan.

\section{Tahap-3 : Materi}

Inti kegiatan sosialisasi pengabdian berada pada tahap ini. Tim sosialisasi pengabdian akan memberikan beberapa materi, yaitu mengenai : Sejarah BPR dalam Sistem Keuangan di Indonesia, Arsitektur Perbankan Indonesia (API), Posisi Strategis Bank Perkreditan Rakyat, Struktur Mekanisme Pengelolaan Bank Perkreditan Rakyat, Kebijakan Penerimaan dan Identifikasi Nasabah, Kebijakan Pemantauan Dan Pelaporan, Prosedur Penerimaan Nasabah, Sejarah Bank Pembiayaan Rakyat Syariah (BPRS), Usaha-Usaha BPR Syariah, Modal Pendirian BPRS, Ketentuan Kehati-Hatian BPRS

\section{Hasil dan Pembahasan}

\section{Sejarah BPR dalam Sistem Keuangan di Indonesia}

Pengertian Bank Perkreditan Rakyat, adalah lembaga keuangan bank yang menerima simpanan hanya dalam bentuk deposito berjangka, tabungan, dan/atau bentuk lainnya yang dipersamakan dengan itu dan menyalurkan dana sebagai usaha BPR. Status BPR diberikan kepada bank desa, lumbung desa, bank pasar, bank pegawai, lumbung pitih nagari (LPN), lembaga perkreditan desa (LPD), badan kredit desa (BKD), badan kredit kecamatan (BKK), kredit usaha rakyat kecil (KL) Lembaga perkreditan kecamatan (LPK), bank karya prod, desa (BKPD), dan/atau lembaga-lembaga lainnya dipersamakan dengan itu berdasarkan UU Perbankan Nonmu 7 Tahun 1992 dengan memenuhi persyaratan tatacara yaw ditetapkan dengan Peraturan Pemerintah.

Landasan hukum bank perkreditan rakyat, landasan hukum BPR adalah UU No. 7/1992 tentang Perbankan sebagaimana telah diubah dengan UU No. 10/1998. Daiam UU tersebut secara tegas disebutkan bahwa BPR sebagai satu jenis bank yang kegiatan usahanya terutama ditujukan untuk melayani usahausaha kecil dan masyarakat di daerah pedesaan. Dalam pelaksanaan kegiatan usahanya BPR hanya dapat melakukan single window, yaitu hanya dapat menjalankan usahanya secara konvensional saja. Bagi BPR tidak terbuka peluang untuk melakukan secara bersamaan, apapun kegiatan usaha yang membentuk perbankan konvensional dan kegiatan usaha perbankan berdasarkan prinsip syariah. Artinya, bagi BPR tidak dimungkinkan untuk melakukan kedua jenis kegiatan usaha perbankan itu secara bersama-sama, sekalipun dilakukan oleh cabang secara khusus. (Munir Fuady, 1999).

Ketentuan tersebut diberlakukan karena mengingat bahwa lembaga-lembaga tersebut telah berkembang dari lingkung masyarakat Indonesia, serta masih diperlukan masyarakat, maka keberadaan lembaga dimaksud diakui. Oleh karena itu, UU Perbankan No. 7/1992 memberikan kejelasan status lembaga-lembaga dimaksud. Untuk menjamin kesatuan dan keseragaman dalam pembinaan dan pengawasan, matal persyaratan dan tata cara pemberian status lembaga-lembaga dimaksud ditetapkan dengan Peraturan Pemerintah.

Visi dan Misi Bank Perkreditan Rakyat, Visi : Terwujudnya industri BPR yang sehat, kuat, produktif, dan dipercaya untuk melayani UMK dan masyarakat, khususnya di pedesaan guna mendukung pertumbuhan perekonomian daerah. 
Misi: Menciptakan kondisi yang kondusif untuk mendorong peningkatan kinerja dan pelayanan BPR kepada UMK dai masyarakat setempat, terutama di wilayah pedesaan.

Lembaga-lembaga keuangan kecil dan lembaga-lembaga lainnya yang dipersamakan dengan itu dapat diberikan status sebagai BPR. dengan memenuhi persyaratan dan tata cara yang ditetapkan dengan peraturan pemerintah (PP). Selanjutnya PP No.71/1992 memberikan jangka waktu sampai dengan Oktober 1997. Bagi lembaga-lembaga keuangan tersebut untuk memenuhi persyaratan menjadi BPR. Sampai dengan batas waktu yang ditetapkan. Adapun kegiatan yang dilakukan oleh BPR antara lain: Kegiatan usaha yang dapat dilakukan BPR: 1). Menghimpun dana dari masyarakat dalam bentuk simpanan berupa deposito berjangka, tabungan dan/ atau bentuk lainnya yang dipersamakan dengan itu. 2). Memberikan kredit, 3). Menempatkan dananya dalam bentuk Sertifikat Bank Indonesia (SBI), deposito berjangka, sertifikat deposito dan atau tabungan pada Bank lain.

Kegiatan usaha yang tidak dapat dilakukan oleh BPR: 1). Menerima simpanan berupa giro dan ikut serta dalam lalu lintas pembayaran. 2). Melakukan kegiatan usaha dalam valuta asing kecuali sebagai pedagang valuta asing (dengan izin Bank Indonesia). 3). Melakukan penyertaan modal. 4). Melakukan usaha perasuransian. 5). Melakukan usaha lain di luar kegiatan usaha.

\section{Arsitektur Perbankan Indonesia (API)}

Dalam rangka memperkuat fundamental industry perbankan serta memberikan arah dan strategi perbankan kedepan telah disusun Arsitektur Perbankan Indonesia (API). API merupakan suatu kerangka dasar sistem perbankan di Indonesia yang bersifat menyeluruh dan memberikan arah, bentuk, dan tatanan industri perbankan untuk rentang waktu sampai sepuluh tahun berlandaskan visi mencapai suatu sistem perbankan yang sehat, kuat, serta efisien, guna menciptakan kestabilan sistem keuangan dalam rangka membantu pertumbuhan ekonomi nasional. Untuk mencapai visi tersebut, salah satu sasaran yang ingin dicapai yaitu menciptakan struktur perbankan domestik yang sehat dan mampu memenuhi kebutuhan masyarakat serta mendorong pembangunan ekonomi nasional yang berkesinambungan.

Melalui kebijakan tersebut diharapkan dapat tercapai struktur perbankan yang terdiri dari empat strata bank yaitu :

a. Bank internasional yang memiliki kapasitas dan kemampuan beroperasi di wilayah internasional serta memiliki modal di atas Rp50 triliun.

b. Bank nasional yang memiliki cakupan usaha sangat luas dan beroperasi secara nasional serta memiliki modal antara Rp. 10 triliun sampai dengan Rp. 50 triliun.

c. Bank dengan fokus usaha tertentu yaitu bank yang kegiatan usahanya terfokus pada segmen usaha tertentu sesuai dengan kapabilitas dan kompetensi masing-masing bank serta memiliki modal antara Rp. 100 miliar sampai dengan Rp 10 triliun.

d. BPR dan bank dengan kegiatan usaha terbatas yang memiliki modal di bawah Rp 100 miliar.

e. Dalam rangka mencapai visi tersebut di atas, program- program API telah memberikan perhatian pada perlunya penguatan permodalan, kelembagaan dan manajemen BPR, serta penyempurnaan pengaturan dan pengawasan 
BPR.

\section{Posisi Strategis Bank Perkreditan Rakyat}

Disadari bahwa selama ini sebagian besar pengusaha mikro dan kecil, serta masyarakat di daerah pedesaan belum mendapatkan pelayanan jasa keuangan perbankan baik dari aspek pembiayaan maupun penyimpanan dana. Adapun lembaga keuangan yang tepat dan strategis untuk melayani kebutuhan masyarakat tersebut adalah BPR dengan pertimbangan:

a. BPR merupakan lembaga intermediasi sesuai dengan UU Perbankan.

b. BPR merupakan lembaga keuangan yang diatur dan diawasi secara ketat oleh Bank Indonesia.

c. Adanya penjaminan oleh LPS atas dana masyarakat yang disimpan di BPR.

d. BPR berlokasi di sekitar UMK dan masyarakat pedesaan, serta memfokuskan pelayanannya sesuai dengan kebutuhan masyarakat tersebut.

e. BPR memiliki karakteristik operasional yang spesifik yang memungkinkan BPR dapat menjangkau dan melayani UMK dan masyarakat pedesaan. Posisi BPR yang strategis tersebut perlu dipertahankan dan diangkat agar keberadaan BPR memberikan manfaat yang lebih besar bagi masyarakat dan mendorong perekonomian casrah daerah.

\section{Struktur Mekanisme Pengelolaan Bank Perkreditan Rakyat}

Penghimpunan Dana BPR, Penghimpunan dana pada BPR meliputi: a). Dana masyarakat merupakan sumber dana utama bagi suatu bank, mengingat dana masyarakat ini merupakan bagian terbesar dari keseluruhan sumber dana yang diperoleh bank, b). Dana pihak ketiga BPR terdiri dari deposito berjangka dan tabungan, c). Dana bank-bank lain, d). Dana bank atau modal bank berasal dari para pemegang saham, e). Fungsi modal adalah di samping untuk mengembangkan usaha juga dimaksudkan untuk menutup resiko yang mungkin terjadi, f). Dana bank lain pada umumnya bersifat pelengkap dan dana tersebut digunakan antara lain untuk melancarkan likuiditas atau mengembangkan usaha.

Penyaluran Dana BPR, Penyaluran dana kepada masyarakat disebut dengan pemberian kredit oleh Bank Konvensional atau pembiayaan oleh bank syariah (Bank berdasarkan prinsip Syariah), pengelolaan kredit harus dilakukan berdasarkan prinsip kehati-hatian, sehingga dapat memberikan kontribusi yang optimal, bank wajib mempunyai keyakinan atas kemampuan debitur untuk melunasi hutangnya dengan melakukan penilaian terhadap watak, kemampuan, modal, agunan dan prospek usaha debitur. penyaluran dana tidak boleh terpusat pada peminjam tertentu (diatur dalam ketentuan BMPK). Penyaluran dana antar bank dilakukan untuk berbagai tujuan guna membantu kegiatan bank satu sama lain.

\section{Kebijakan Penerimaan dan Identifikasi Nasabah}

BPR wajib mempunyai kebijakan tentang penerimaan dan identifikasi calon nasabah yang sekurang-kurangnya mencakup hal-hai sebagai berikut: a). Permintaan informasi mengenai calon nasabah antara lain: 1). Identitas calon nasabah. 2). Maksud dan tujuan hubungan usaha yang akan dilakukan oleh calon nasabah dengan BPR. 3). Informasi lainyangmemungkinkan BPRdapatmengetahui profil calon nasabah. 4). Identitas pihak lain, dalam hal calon nasabah bertindak untuk dan atas nama pihak lain, b). Permintaan bukti- 
bukti identitas dan dokumen pendukung informasi dari calon nasabah, c). Penelitian atas kebenaran bukti-bukti identitas dan dokumen pendukung informasi dari calon nasabah, baikyang bertindak atas nama diri sendiri maupun sebagai perantara dan atau kuasa pihak lain (beneficial owner).

Pertemuan dengan calon nasabah dilakukan sekurang- kurangnya pada saat pembukaan rekening termasuk pembukaan rekening secara elektronis, apabila dipandang perlu dapat dilakukan wawancara dengan calon nasabah untuk memperoleh keyakinan atas kebenaran informasi, bukti-bukti identitas dan dokumen pendukung calon nasabah. Menolak untuk membuka rekening dan atau menolak melaksanakan transaksi dengan calon nasabah apabila: BPR tidak memperoleh dokumen dan informasi secara lengkap mengenai informasi calon nasabah setelah melakukan langkah-langkah seperti yang telah di jelaskan.

Diketahui menggunakan identitas dan atau memberikan informasi yang diragukan kebenarannya.Kebijakan dan prosedur penerimaan nasabah berlaku pula bagi nasabah yang tidak memiliki rekening di BPR (walk-in customer) dalam hal transaksi yang dilakukan melebihi Rp100.000.000 (seratus juta rupiah) atau nilai yang setara, baik dilakukan dalam 1 (satu) kali transaksi maupun beberapa kali transaksi dalam 1 (satu) hari kerja.

\section{Kebijakan Pemantauan Dan Pelaporan}

BPR wajib memiliki kebijakan tentang pemantauan rekening dan transaksi nasabah yang mencakup sekurang-kurangnya hal- hal sebagai berikut: a). Penatausahaan dokumen yang berkaitan dengan identitas nasabah, termasuk perantara atau kuasa pihak lain (beneficial owner), dalam jangka waktu sekurangkurangnya 5 (lima) tahun sejak nasabah menutup rekening, dan penatausahaan dokumen untuk nasabah yang tidak memiliki rekening di BPR (walk-in customer) sekurang-kurangnya 5 (lima) tahun sejak transaksi dilakukan, b). Pengkinian (updating) data dalam hal terdapat perubahan dokumen yang ditetapkan sebagaimana dimaksud dalam angka 1 di atas.

Pemeliharaan sistem pencatatan yang secara efektif dapat membantu petugas BPR dalam melakukan identifikasi, analisis, pemantauan dan penyediaan laporan mengenai transaksi yang dilakukan oleh nasabah. Sistem pencatatan ini memungkinkan BPR untuk dengan mudah menelusuri setiap transaksi (individual transaction), baik untuk keperluan internal BPR dan atau Bank Indonesia maupun dalam kaitannya dengan kasus peradilan. Dalam melaksanakan kemitraan antara bank dan nasabahnya, untuk terciptanya sistem bank yang sehat, kegiatan BI perlu dilandasi dengan beberapa asas hukum. (Usman, Rachmadi : 2001)

Pemeliharaan profil nasabah yang sekurang-kurangnya mencakup informasi mengenai: 1). Identitas nasabah, 2). Pekerjaan atau bidang usaha, 3). Jumlah penghasilan, 4). Rekening yang dimiliki, 5). Aktivitas transaksi normal, 6). Tujuan pembukaan rekening. 7). Pertimbangan untuk menolak melaksanakan transaksi dan atau memutuskan hubungan usaha, 7). Pelaporan Transaksi Keuangan Mencurigakan kepada PPATK bersifat rahasia dan tidak diberitahukan kepada nasabah yang bersangkutan.

\section{Ketentuan Kehati-Hatian BPR}

Kewajiban Penyediaan Modal Minimum (KPMM), BPR diwajibkan untuk memenuhi rasio KPMM minimal $8 \%$ yang dihitung dari perbandingan antara modal dengan Aktiva Tertimbang Menurut Risiko (ATMR). Komponen modal 
terdiri dari modal inti dan modal pelengkap, dimana modal pelengkap maksimum sebesar $100 \%$ dari modal inti. Modal inti terdiri dari modal disetor, agio, dana setoran modal, modal sumbangan, cadangan umum, cadangan tujuan, laba ditahan (setelah penghitungan pajak), laba tahun-tahun lalu, dan laba tahun berjalan.

Bank Indonesia (Bl) akan menerbitkan aturan zonasi pendirian Bank Perkreditan Rakyat (BPR) berdasarkan modal. (Eko Prasetyo, 2019). Aturan modal minimum yang dikaitkan dengan zonasi atau daerah ekspansi tidak hanya berlaku pada bank umum, aturan ini juga akan diterapkan pada industri bank perkreditan rakyat (BPR). Saat ini Bank Indonesia sedang melakukan pengkajian mengenai besaran modal dan pembagian wilayah. Zonasi pendirian BPR akan dilakukan berdasarkan potensi ekonomi dan perputaran uang di daerah masingmasing.

\section{Prosedur Penerimaan Nasabah}

Calon nasabah, melakukan pengisian formulir lengkap, pengisian formulir standar yang ditetapkan oleh BPR sekurangkurangnya memuat informasi: 1). nama, tempat dan tanggal lahir, alamat serta kewarganegaraan yang dibuktikan dengan kartu tanda penduduk (KTP), surat izin mengemudi (SIM) atau paspor dan dilengkapi dengan informasi mengenai alamat tinggal tetap apabila berbeda dengan yang tertera dalam dokumen. Khusus warga negara asing (WNA) selain paspor dibuktikan dengan kartu izin menetap sementara (KIMS/KITAS) atau kartu izin tinggal tetap (KITAP), 2). Alamat dan nomor telepon tempat bekerja yang dilengkapi dengan keterangan mengenai kegiatan usaha perusahaan/instansi tempat bekerja, 3). keterangan mengenai pekerjaan/jabatan dan penghasilan calon nasabah.

Dalam hal calon nasabah tidak memiliki pekerjaan, maka data yang diperlukan adalah sumber pendapatan, keterangan mengenai sumber dan tujuan penggunaan dana, spesimen tanda tangan., apabila diperlukan BPR dapat meminta informasi lain antara lain berupa identitas pemberi kerja dari calon nasabah, rekening telepon dan rekening listrik, khusus untuk calon nasabah yang melakukan pembukaan rekening melalui telepon, surat menyurat atau electronic banking maka petugas BPR wajib melakukan pertemuan dengan calon nasabah sebelum pembukaan rekening tersebut disetujui.

Prosedur identifikasi dan penerimaan nasabah, berdasarkan dokumen pendukung yang telah disampaikan oleh calon nasabah, BPR wajib melakukan identifikasi dan verifikasi yang sekurang-kurangnya:1). Meneliti kebenaran dokumen dan mengidentifikasi adanya kemungkinan hal-hal yang tidak wajar atau mencurigakan. 2). Menatausahakan fotokopi dokumen setelah dilakukan pencocokan dengan dokumen asli yang sah. 3). Melakukan pertemuan dengan calon nasabah sebelum pembukaan rekening tersebut disetujui bagi calon nasabah yang menggunakan media elektronis, telepon dan surat menyurat.

Pertemuan BPR dengan calon nasabah dilakukan untuk meyakini identitas calon nasabah dan menilai kewajaran informasi yang diberikan oleh calon nasabah. 4). Melakukan pengecekan silang untuk memastikan adanya konsistensi dari berbagai informasi yang disampaikan oleh calon nasabah. Melakukan verifikasi yang lebih ketat (extensive due dilligence) terhadap calon nasabah. Persetujuan penerimaan calon nasabah diberikan oleh pejabat BPR sesuai dengan jenjang kewenangan yang ditetapkan setelah meyakini kebenaran identitas dan kelengkapan dokumen calon nasabah. 


\section{Sejarah Bank Pembiayaan Rakyat Syariah (BPRS)}

Tujuan BPR Syariah, adapun tujuan yang dihendaki dengan berdirinya BPR Syariah, antara lain : a). Meningkatkan kesejahteraan ekonomi umat islam, terutama masyarakat dari golongan ekonomi lemah yang pada umumnya berada di pedesaan, b). enambah lapangan pekerjaan terutama ditingkat kecamatan, sehingga dapat mengurangi tingkat urbanisasi, c). Membina semangat ukuwah islamioh melalui kegiatan ekonomi dalam rangka meningkatkan pendapatan perkapita menuju kualitas hidup yang memadai.

Perbedaan BPR, BPRS dan Bank Syariah, secara umum dilihat dapat diketahui bahwa BPR dan BPRS hampir memiliki kesamaan, hal tersebut dikarenakan BPRS berdiri karena pengaruh berdirinya BPR yang sebelumnya telah didirikan. Hal yang membedakan BPR dengan BPRS adalah pada prinsip operasional. BPR dapat menjalankan kegiatan operasinya secara konvensional juga syariah. Namun pada kenyataannya, BPR lebih sering bahkan hanya menggunakan prinsip konvensional pada setiap kegiatannya. Sedangkan BPRS hanya menjalankan kegiatannya berdasarkan prinsip syariah saja.

Untuk perbedaan BPRS dengan Bank Syariah, terdapat pada lingkup kegiatan. BPRS hanya melalukan kegiatan di satu wilayah tertentu sedangkan lingkup kegiatan Bank Syariah dapat mencangkup jangkauan dunia. Untuk kegiatan BPRS sama dengan kegiatan BPR, baik kegiatan yang diperbolehkan maupun kegiatan yang tidak perbolehkan. Kegiatan BPRS hanya dibatasi dalam menghimpun dan menyalurkan dana. Sedangkan kegiatan Bank Syariah lebih luas dari pada BPRS. Namun, BPRS memiliki karakter operasional yang spesifik sehingga dapat memfokuskan untuk melayani masyarakat pedesaan juga UMK (Usaha Mikro Kecil).

Perbedaan BPR - BPRS - Bank Syariah

\begin{tabular}{|l|c|c|c|}
\hline \multicolumn{1}{|c|}{ Faktor } & BPR & BPRS & Bank Syariah \\
\hline Prinsip Usaha & Konvesional & Syariah & Syariah \\
\hline Ruang Lingkup & Nasional & Nasional & Intrernasional \\
\hline Kegiatan Usaha & Dibatasi & Dibatasi & Tidak Dibatasi \\
\hline & Deposito, & Deposito, & Deposito, \\
Sumber Dana & Tabungan & Tabungan & Tabungan, dan \\
& & & Simpanan Lain \\
\hline
\end{tabular}

\section{Usaha-Usaha BPR Syariah}

Pada dasarnya sebagai lembaga keuangan syariah, BPRS dapat memberikan jasa keuangan yang serupa dengan bank syariah. Pembatasan usaha BPRS secara lebih tegas dijelaskan dalam Pasal 27 SK Direktur Bl No. 32/36/KEP/DIR/1999, kegiatan operasional $B P R S$ adalah: a). Menghimpun dana dari masyarakat dalam bentuk simpanan yang meliputi: 1). Tabungan berdasarkan prinsip wadiah atau mudarabah. 2). Deposito berjangka berdasarkan prinsip mudarabah. 3). Bentuk lain yang menggunakan prinsip wadiah atau mudarabah. Melakukan penyaluran dana melalui: a). Transaksi jual beli berdasarkan prinsip : mudarabah, istisna, ijarah, salam, jual beli Lainnya. Pembiayaan bagi hasil berdasarkan prinsip : mudarabah, musyarakah, bagi hasil lainnya. Pembiayaan Lain berdasarkan prinsip : rahn, qard.

Usha-usaha yang dilakukan oleh BPRS harus dilaporkan oleh direksi BPRS kepada Otoritas Jasa Keuangan, paling lambat terhitung 10 hari sejak tanggal 
pelaksanaan kegiatan usaha, apa bila izin telah diberikan, namun tidak ada kegiatan yang dilaksanakan, maka izin usaha BPRS di cabut alias dinyatakan tidak berlaku. (Dsrmanwan, 2020). Maka wajib BPRS dalam waktu tempo 10 hari tersebut ada rekam jejak melaksanakan suatu kegiatan yang berkaitan dengan BPRS.

\section{Modal Pendirian BPRS}

Bank Indonesia bertindak selaku pengatur, pembina dan pengawas, tidak saja mengatur Bank Konvensional malainkan juga bagi Bank Syariah. (UndangUndang Nomor 23 Tahun 1999 tentang Bank Indonesia Pasal 8). Berdasarkan Peraturan Bank Indonesia PBI No. 11/23/ PBI/2009, modal yang harus disetor untuk mendirikan BPRS ditetapkan sekurang-kurangnya sebesar: a). Rp 2.000.000.000,- (dua milyar rupiah) untuk BPRS yang didirikan di wilayah Daerah Khusus Ibu kota Jakarta Raya dan kabupaten/ kotamadya Tangerang, Bogor, Bekasi, dan Karawang, b). Rp 1.000.000.000,- (satu milyar rupiah) untuk BPRS yang didirikan di wilayah ibu kota provinsi di luar wilayah, c). Rp 500.000.000,- (lima ratus juta) untuk BPRS yang didirikan di luar wilayah. Sedangkan modal yang di setor untuk mendirikan BPRS berdasarkan zonasi, paling sedikit: a). Zona 1 Rp. $12.000 .000 .000,00$, b). Zona 2 Rp. 7.000.000.000,00. c). Zona 3 Rp. 5.000.000.000,00, d). Zona 4 Rp. 3.500.000.000,00. (Darmawan Muhammad, 2020).

Modal yang disetor tersebut, yang digunakan untuk modal kerja bagi BPRS, wajib sekurang-kurangnya berjumlah 50\%. Dengan kata lain, nilai investasi dalam rangka pendirian BPRS itu tidak boleh melebihi 50\% dari modal yang disetor oleh pendirinya. Sumber dana yang digunakan dalam rangka kepemilikan dilarang: 1). Berasal dari pinjaman atau fasilitas pembiayaan dalam bentuk apapun dari Bank dan atau pihak lain di Indonesia, 2). Berasal dari sumber yang diharamkan menurut prinsiip syariah adalah termasuk kegiatan-kegiatan yang melanggar hukum.

\section{Simpulan}

Kegiatan Pengabdian ini dilakukan dalam bentuk sosialisasi. Sosialisasi ini dilakukan selama 2 hari yaitu pada Hari/ Tanggal: Kamis-Jum'at/ 8-9 Oktober 2020. Adapun peserta sosialisasi ini adalah alumni pondok pesanteren Al-Iman yang ada di Palembang. Jumlah peserta sosialisasi ini sebanyak 15 (lima belas) orang. Hasil kegiatan sosialisasi ini dapat diketahui bahwa persentasi peserta sebanyak 15 orang. Berdasar hasil pelaksanaan kegiatan pengabdian kepada masyarakat ini dan uraian pembahasan di atas, dapat disimpulkan beberapa hal sebagai berikut :

1. Tindak Lanjut Hasil sosialisasi

Evaluasi pelaksanaan sosialisasi menjadi dasar untuk mengetahui pemahaman materi yang di sosialisasikan. materi dan pemahaman alumni dalam mengikuti sosialisasi:

\begin{tabular}{|c|c|}
\hline Materi & $\begin{array}{c}\text { Keterangan }(\%) \\
\text { Pemahaman }\end{array}$ \\
\hline \multicolumn{2}{|l|}{ Hari Pertama: } \\
\hline Sejarah BPR dalam Sistem Keuangan di & $80 \%$ \\
\hline
\end{tabular}




\begin{tabular}{|l|l|}
\hline Indonesia & \\
\hline Arsitektur Perbankan Indonesia (API) & $85 \%$ \\
\hline Posisi Strategis Bank Perkreditan Rakyat & $90 \%$ \\
\hline $\begin{array}{l}\text { Struktur Mekanisme Pengelolaan Bank } \\
\text { Perkreditan Rakyat }\end{array}$ & $82 \%$ \\
\hline Ketentuan Kehati-Hatian BPR & $86 \%$ \\
\hline Hari Kedua: \\
\hline Kebijakan Penerimaan dan Identifikasi Nasabah & $88 \%$ \\
\hline Kebijakan Pemantauan dan Pelaporan & $85 \%$ \\
\hline Prosedur Penerimaan Nasabah & $83 \%$ \\
\hline $\begin{array}{l}\text { Sejarah Bank Pembiayaan Rakyat Syariah } \\
\text { (BPRS) }\end{array}$ & $90 \%$ \\
\hline Usaha-Usaha BPR Syariah & $87 \%$ \\
\hline Modal Pendirian BPRS & $84 \%$ \\
\hline
\end{tabular}

2. Memperpanjang masa sosialisasi, melalui jalinan silaturahim antar masingmasing individu alumni pondok pesntren Al-Iman yang ada di Palembang, melalui sosial media, seperti WA grup yang mempermudah komunikasih.

\section{Daftar Pustaka}

Darmawan. Muhammad, Fasa,Iqbal. Menejemen Keuangan Syariah. Yogyakarta: UNY Press

Fuady, Munir. 1999. Hukum Perbankan Modern (Berdasarkan Undang-Undang Tahun 1998), Buku Kesatu. Bandung: Citra Aditya Bakti.

Usman, Rachmadi. 2001. Aspek-aspek Hukum Perbankan di Indonesia. Jakarta : Gramedia Pustaka Utama

Prasetyo, Eko. 2019. Memiliki BPR itu Mudah. Seleman: Budi Utama.

Undang-Undang Nomor 23 Tahun 1999 tentang Bank Indonesia. Pasal 8, 10, dan 11. kemudian di ubah UndangiUndang Nomor 3 Tahun 2004 yang kemudian untuk kedua kali di ubah dengan Peraturan Pemerintah Pengganti Undang-Undang Nomor 2 Tahun 2008 yang selanjutnya ditetapkan menjadi undang-undang melalui Undang-Undang Nomor 6 Tahun 2009

\section{Dari Internet:}

https://www.bpramira.com/2018/07/12/sejarah-singkat-bpr-bank-perkreditanrakyat/

Bank Indonesia, Sekilar Perbankan Syariah Di Indonesia, http://www.bi.go.id/web/id/Perbankan/Perbankan+Syariah/ diakses 25 Agustus 2012. 